\title{
Othering Mushrooms: Migratism and its racist entanglements in the Brexit campaign
}

\author{
Lenka Vráblíková ${ }^{1 *}$
}

Published: March 5, 2021

\begin{abstract}
Mushrooms have long occupied a highly ambivalent position in the cultural imagination, inciting disgust and fear, as well as wonder and fascination. Neither plants, nor animals, they grow up unexpectedly but also in regular lines or circles. Some of them are medicinal and edible, whereas others are toxic or even poisonous. Sometimes they are both. Employing the ambivalence of mushrooms as an analytic lens, this article interrogates the processes of othering through which certain bodies are more susceptible to be othered than other bodies. Mobilising Sara Ahmed's analytic framework on othering as an embodied process, this transnational ecofeminist intervention provides an insight into how forests, mushrooms and their foragers have been deployed in the Brexit campaign's migratism and explores its racist entanglements. The article argues that research into social and environmental histories of how meaning is constructed and embodied in human and non-human bodies and the places they inhabit is vital for contesting the reemergence of the right-wing populism that, in Europe, is exemplified by events such as Brexit.
\end{abstract}

Keywords: Brexit, feminist ethnomycology, embodied othering, migratism/racism/antisemitism, media \& communication

\section{INTRODUCTION}

Mushrooms have long occupied a highly ambivalent position in the cultural imagination, inciting disgust and fear, as well as wonder and fascination. Neither plants, nor animals, they grow up unexpectedly but also in regular lines and circles. Some of them are medicinal and edible, whereas others are toxic or even poisonous; sometimes they are both. Ethnomycology - a branch of study which 'explores various uses, beliefs, and practices connected with fungi and mushrooms that exist in different cultures' (Yamin-Pasternak, 2011: 213) - argues, that the ambivalence in attitudes towards these organisms is a result of their diverse ecology, unbounded biology and highly variable biodiversity, combined with the limited knowledge humans have about them. ${ }^{1}$ This ambivalence has elicited extreme and polarised sentiments, leading Valentina and Gordon Wasson (1957), the founders of ethnomycology, to describe cultures that embrace and esteem mushrooms - such as the Slavic culture from which both Valentina and I come from - as 'mycophilic', and those that disdain them - such as the Anglo-Saxon culture, the culture of her husband Gordon, as 'mycophobic'.

Contributing to the recent scholarship conducted with fungi to study key socio-cultural and environmental phenomena such as migration, precarity and ecological emergency (Bahng, 2017; Sheldrake, 2020; Tsing, 2015), I propose examining mycophobia and mycophilia not as exclusive binaries but as critically entangled and mutually constitutive cultural positions. I deploy the ambivalence of mushrooms in cultural imagination to the analysis of visual and textual elements of media discourse to examine how forests, mushrooms and their foragers have figured as tropes of othering in the Brexit campaign's migratism and to explore its racist entanglements. The examination draws from two strands of scholarship. The first is the work that has examined how forests and mushrooms have figured in the discursive and material formations of nation-belonging in modern Europe that also has been enabled and implemented across the world through colonialism (Rose, 2008; Schama, 1996; Tsing, 2005; 2015). The second involves the critical theorisations of race and racism. I draw from scholars who conceptualise migratism - 'the

${ }^{1}$ Although it is estimated that there are between 2.2 and 3.8 million species of fungi - which is six times more than plants and twice as many as animals - only about 6 percent of fungi species have been described so far (Sheldrake, 2020: 16). 
discrimination based on the ascription of migration' (Tudor, 2017: 23-24) - as different from but intimately linked with racism, and who examine their interlacing particularly in relation to Brexit (Bhambra, 2017; Virdee and McGeever, 2018). ${ }^{2}$

I conceptualise 'othering' as a complex set of differentiating temporal and spatial bodily encounters along the established binary trope native/alien and its correlates human/non-human, citizen/foreigner, male/female civilised/primitive, Global North/South and West/East. This conceptualisation draws from the work of feminist (and) postcolonial scholars who have theorised othering as a contextual, contradictory and fluid process (Bhabha, 1983; hooks, 1992), and particularly Sara Ahmed's theorisation articulated in Strange Encounters: Embodied others in post-coloniality (2000). Focusing on how 'othering' operates in relation to embodiment and community, Ahmed postulates that subjectivities are embodied as a result of a singular lived experience formed by a complex set of differentiating temporal and spatial encounters with bodily others and the world. To critically examine the configurations of a mode of encountering that has dominated the world since the beginning of European colonial modernity, and that has benefited those who have been associated with white, masculine, heterosexual, cisgender and non-disabled bodies dwelling in the Global North and/or West at the expense of those who have not, Ahmed coined a notion 'stranger fetishism' (2000: 3-6). In this mode, the subjectivities of the beneficiaries are established through bodily encounters that produce a figure of a particular kind of others Ahmed calls 'strangers' (2000: 2930). The process of estranging consists in differentiations between various kinds of others that rely on already established metonymic associations that position certain others as already read and recognised as strange, and by detaching these bodily others from social histories that have determined their figuration in the first place (Ahmed, 2000: 56). According to Ahmed's analysis, both expulsion and incorporation are tools that feed from and reproduce fetishism through which strangeness is made intrinsic to the bodies of these particular others. Whereas the former figures strangers as dangerous - informing criminal prevention discourses or neighbourhood watch programmes (2000: 21-38) - the latter interprets their difference as beneficial and thus welcomes it - an approach that characterises multiculturalism and cultural diversity discourses (2000: 95-113). Finally, Ahmed (2000: 6) postulates that it is not only the boundaries of individual bodies that are constituted, reinforced and legitimated through stranger fetishism but also the 'we' and 'them' of their communities and spaces they inhabit such as the streets, neighbourhoods, and nation states, as well as epistemic communities.

Developing from Ahmed and other scholars mentioned above, I argue that research into social and environmental histories of how meaning is constructed and embodied in human and non-human bodies and the places they inhabit is vital for ensuring the success of the efforts to contest the recent re-emergence of the rightwing populism that, in Europe, is exemplified by events such as Brexit. The analysis proceeds through a case study - a newspaper article 'Eastern European mushroom mobs: New Forest is stripped bare by fungi rustlers' (Perring, 2015) published in The Daily Express, one of the British national middle-market tabloid newspapers that played a key role in supporting the Brexit campaign. In the following section, I closely examine the techniques of othering deployed in the newspaper article. The next section shows how its discourse on forests, mushrooms and their forages echoes a myth of greenwood freedom that has been instrumental to the formation of English nationalism and that has been narrated in England and later in the United Kingdom (UK) since the Middle Ages. The second part of the article unpacks the racist entanglements of the Brexit campaign's migratism. Drawing particularly from Gurminder K. Bhambra's work (2017), I first argue that the racialised discourse on belonging mobilised in the Brexit campaign has been intrinsically bound to the past and present legacies of British Empire and the European colonial modernity more broadly. The next section develops this point by showing how forests, mushrooms and their foragers have been deployed in European antisemitic discourses, namely a Nazi propaganda book Der Gifttilz. [The Toadstool published by Der Stürmer in 1938, and the history and taxonomy of a mushroom species Auricularia auricula that, in many European languages, is known as 'Judas' ear', and in English by its even more troubling rendering 'Jew's ear'.

\footnotetext{
2 As Alyosxa Tudor (2018: 1057) argues, 'equating racialisation with migratisation carries the risk of whitening understandings of migration and/or reinforcing already whitened understandings of nation and Europeanness'. In my examination of belonging, I use 'migratism' (Tudor, 2017) and 'othering' (Ahmed, 2000) instead of other analytical terms such as xenophobia. In addition to naming 'the discrimination based on the ascription of migration' (Tudor, 2017: 23-34), 'migratism' also indicates the privileged position a figure of a migrant have obtained in popular and scholarly discourses since the 1990s (Ahmed, 2000: 80-86). To explain further, I use 'othering' to analytically capture the complexity of the processes of 'stranger fetishism' (Ahmed, 2000:3-6), and specifically the intertwining of migratisation, racialisation and gendering with the polarised sentiments towards mushrooms.
} 
Feminist Encounters: A Journal of Critical Studies in Culture and Politics, 5(1), 05

\section{MUSHROOM FORAGING, THE BREXIT CAMPAIGN'S MIGRATISM AND THE DAILY EXPRESS}

Brexit is the name for the withdrawal of the UK from European Union (EU), which was decided in British national referendum on 23 June 2016, with the result of $51.9 \%$ of voters voting in favour of leaving the EU (Mcguire, 2019: 257). The Brexit campaign begun to enter the public domain in early 2015. A key point has been stark opposition to immigration presented as a means of reinstating the sovereignty of the British people depicted as being under siege. As Bhambra (2017) and others have shown (Virdee and McGeever, 2018), racist English nationalism - which is bound to the past and present legacies of the British Empire - was central to the Brexit campaign. This was also and perhaps most explicitly revealed in the 'Breaking Point' poster of Eurosceptic, rightwing populist UK Independent Party (UKIP), ${ }^{3}$ which depicted Syrian refugees at the borders of another EU member state, Slovenia, with a subheading 'We must break free of the EU and take back control' (Virdee and McGeever, 2018: 1807-8).

British media, and especially the tabloid press, were instrumental in the fabrication and dissemination of this message (Mcguire, 2019). Coincidentally with the Brexit campaign, another topic appeared in many national newspapers - a call for the strict regulation of mushroom picking in British woodland (see McKie, 2016). The Daily Express, a tabloid newspaper aligned with UKIP and the right-wing fractions of the Conservative Party, managed to contribute to both debates in one piece. In an article with a headline 'Eastern European mushroom mobs: New Forest is stripped bare by fungi rustlers' (Perring, 2015), a reporter informed the British public that '[r]angers patrolling the New Forest are on high alert amid fears black market gangs - many thought to be Eastern Europeans - [who] are stripping the beauty spots of its edible mushrooms'. 'Experts', the reporter continued, 'have warned the gangs could even kill because pickers who don't know the different species are likely to take deadly toadstools and other poisonous fungi in mistake for edible and safe mushrooms'. A spokesman of New Forest Association Brian Tarnoff 'blasted it' as an 'unacceptable theft' that was 'spoiling the Forest's autumn beauty and harming wildlife' (Tarnoff quoted in Perring, 2015). They added that

every year vans full of unskilled labourers descend upon the Forest and indiscriminately strip our woodlands of every bit of fungi they encounter (...) leaving nothing for families on a day's outing in the forest who want a few mushrooms as a mealtime treat.

The reporter further speculated that 'these gangs are thought to include cheap labour in the form of EU immigrants' and brought a testimony by farmer Sara Cadbury who also confirmed that 'the Forest is being exploited and trashed'. Finally, the readers were informed that New Forest was not the only site where the gangs operated but that other forests were also endangered. The article concluded with a demand for clearer policy and strict regulation that would put total ban on mushroom removal.

As the above quotations testify, the newspaper article employs language of othering that is reminiscent of racist and classist condemnations of Irish and Romany Travellers that has a long tradition in UK media (Conboy, 2006) and which - in the aftermath of the so called 'War on Terror' and 'Migration Crisis' - has been used particularly in relation to Muslim communities (Virdee and McGeever, 2018: 1807). In terms of Ahmed's analytical framework, the article employs rhetorical tropes of othering that define what she calls 'stranger danger' discourses (2000: 2137). For instance, the intruders are already known and recognised as the origin of the danger. That the 'mushroom mobs' are 'Eastern Europeans' - a vague and homogenising term used in the UK in disparaging manner to name people from Central and Eastern Europe as well as a synonym specifically for Polish people - is presented as a given and a common knowledge which the reporter shares with those she has interviewed for her article as well as her readers. Their knowability is a result of one of the normalised 'ways of sensing' strangers (Ahmed 2000: 29) that, in British current cultural and political context, has relied on a chain of metonymies unfolding in the following direction: unskilled and cheap labour - EU immigrants - engaging in illegal activities - Eastern Europeans - harm.

The newspaper article mobilises further tropes of othering to portray the danger these intruders represent. The language used to depict their activities invokes a sinister and violent attack whilst expressions such as 'full vans descend every year' or using a plural form of words that already invoke great numbers, such as 'gangs' or 'mobs'which furthermore imply violence or criminal and 'out of control' behaviour-portray the mushroom pickers as being too many, as being overabundant. Additionally, other characters are invoked in order to create the demarcation between 'them' and 'us' and to portray not only the intruders' danger but also the endangered 'we', the 'we' of 'the ordinary men and women' The Daily Express claims to represent (Buckledee, 2011: 61), thus invoking a fantasy of community based upon shared socio-economic status, culture and ethnicity (Conboy, 2006: 94-95).

\footnotetext{
${ }^{3}$ UKIP is a continuation of the Anti-Federalist League founded in 1991. The Party reached its greatest success in the mid2010s when it gained two seats in the British Parliament and became a British political party with the most seats in the European Parliament. The withdrawal of the UK from the EU has been its focus from the start.
}

(C) 2021 by Author/s 
These characters include representatives of the civil society, ordinary citizens as well as authorities, whose policing and surveillance is called upon by the very presence and actions of the intruders.

Importantly, British families are named as those who are impoverished by the commercial mushroom pickers. Families, as Ahmed argues, play a significant role in 'stranger danger' discourses (2000: 32-37). Standing for 'women and children' (Ahmed, 2000: 31), such invocation feeds on and reinforces white heteropatriarchy, employing its fundamental aspect, the compulsory binary gender divide of complementary opposites, where masculinity is portrayed as strong, active and potent and thus as able to attack or protect, and femininity as passive, weak and vulnerable, and thus attackable and in need of protection. In addition to the invocation of families, the feminine coding of the bodies that are portrayed as endangered is achieved by other metonymic associations that are attached to traditionally defined white femininity such as 'beauty', here employed in relation to nature ('the forest's autumn beauty') which, as the newspaper article argues, the intruders 'strip off and 'spoil'. The binary gender division - employed as a metaphor - is thus yet another vehicle for the demarcation between 'us' and 'them', a demarcation which, reversely, reinforces and legitimises white heteropatriarchy. Finally, the mention of families also helps to complexify the article's affective charge. According to Ahmed's reading of racism as a politics of hatred, 'a politics that directs hatred towards others (that creates others as objects to be hated as well as feared) often presents itself as a politics of love' (2013: 227). By portraying themselves as acting out of love, that is to say love for their families, communities, nation or, as in this case, also forests and their wildlife, including edible mushrooms, the newspaper article constitutes 'normal' British citizens - the nature-loving, Anglo-Saxon, white, heterosexual, middle class, cisgender subjects - and portrays the citizens as those who are endangered and thus in need of protection, whilst justifying their fear and hatred of immigrants.

This is achieved through verbal as well as visual means. The two accompanying photographs (Figure 1 and Figure 2) are generic stock images that depict mushrooms growing in their habitat or recently picked and placed in the basket. Importantly however, the images are framed so the face of the person who picked them is not visible. Missing a head, the mushroom forager is depersonalised which erases the singularity of an individual and blends it with a figuration of a monolithic group (of strangers), thus enabling stereotyping and the feeling of hate, as it helps defer empathy, compassion as well as guilt. Despite such depersonalisation, it is nonetheless suggested, from the forager's hands, that they are an adult man with light skin. The assignability of masculine gender to the figure of the dangerous stranger develops and complements the coding of the endangered bodies as feminine invoked in the newspaper article as discussed above.

Another trope of othering that is employed in the photographs, and is central to both of their compositions, is a knife which the faceless light-skinned person coded as masculine holds in their hand. To be sure, a knife - along walking shoes, raincoat, basket, or cloth bag - is among the equipment that is commonly used for mushroom picking. The knife is used for cleaning of the mushrooms, the removal of debris such as soil and needles and for

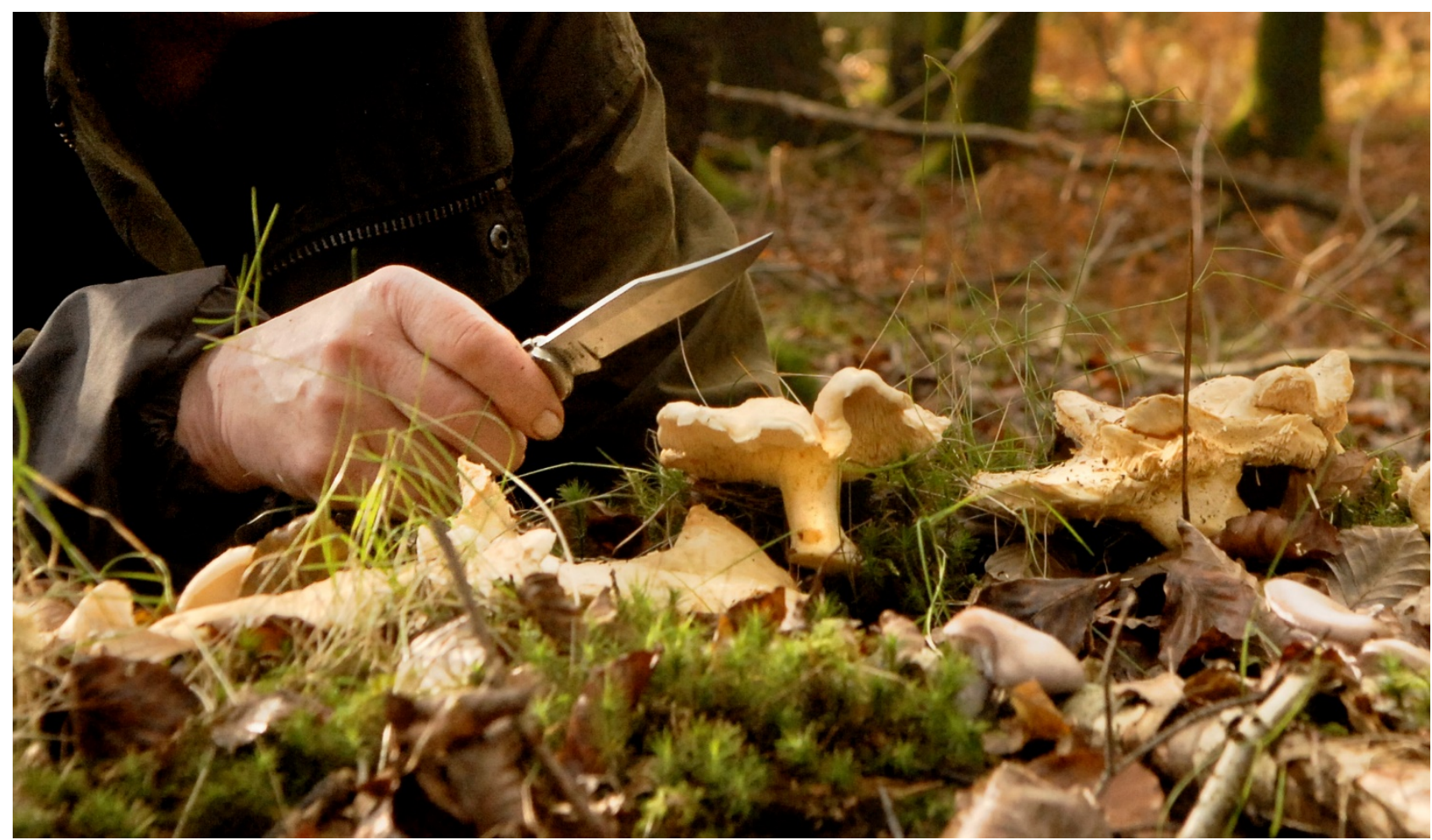

Figure 1. A Photograph accompanying The Daily Express' article 'Eastern European mushroom mobs: New Forest is stripped bare by fungi rustlers' (Perring, 2015). Photo Credit: Solent News and Photo Agency. 


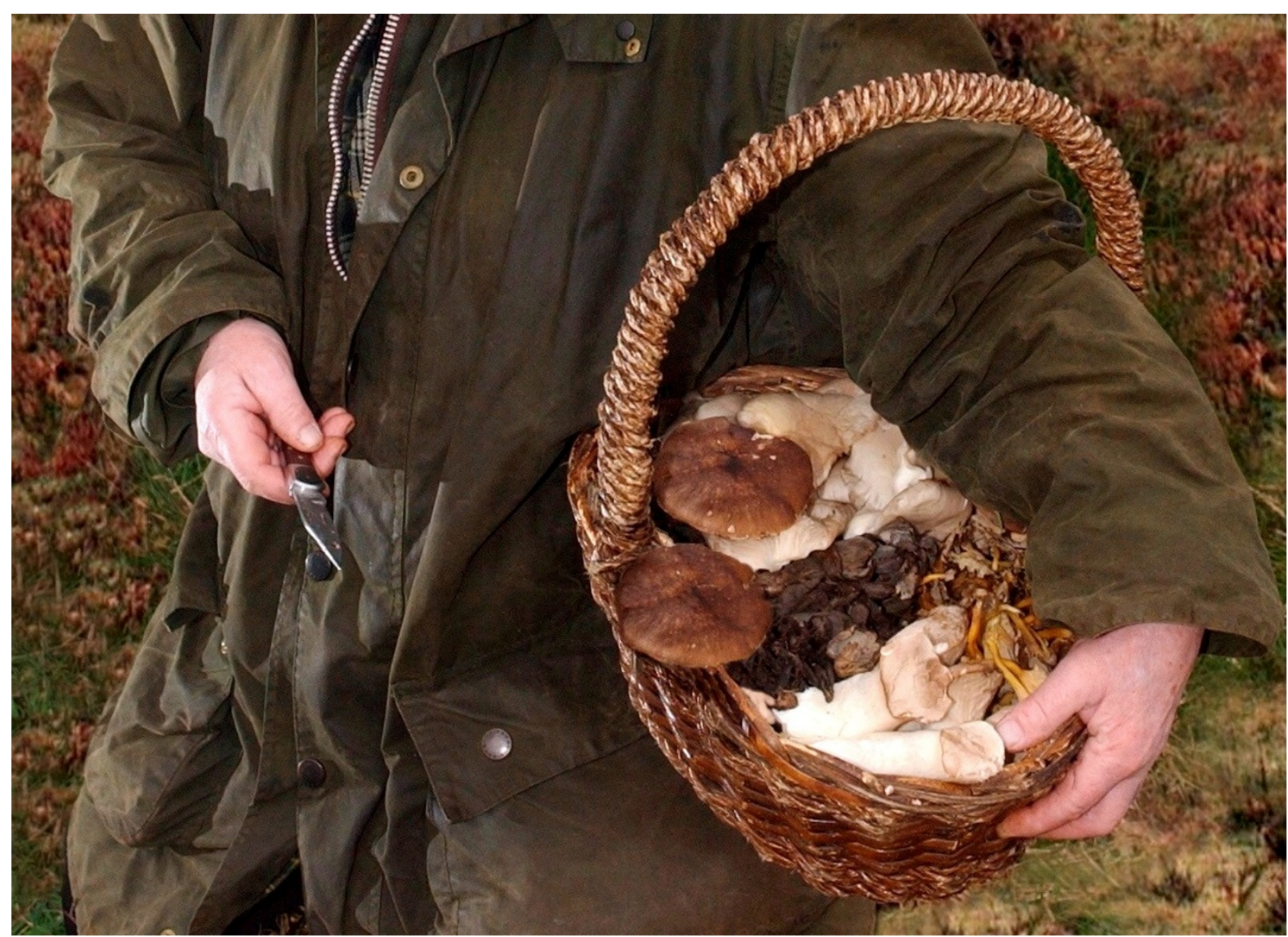

Figure 2. A Photograph accompanying The Daily Express'article 'Eastern European mushroom mobs: New Forest is stripped bare by fungi rustlers' (Perring, 2015). Photo Credit: Solent News and Photo Agency.

carving away the soiled stalk and inedible parts. Another reason that mushroom pickers use knives for foraging is because it helps separate the fruit body (what we usually call mushroom) from the hyphae, the long, individual pieces that comprise a mycelium (a 'root system' which forms the main body of the mushroom), without disturbing or damaging the hyphae, and thus supporting its further growth. As argued, the generic stock images have been carefully constructed to match the content of the article. In these images, a knife therefore does not invoke techniques of careful harvesting but a harmful attack. In one of the photographs (Figure 2), the knife is positioned in the direction of a mushroom that has just been cut. In the other photograph (Figure 1), while one hand protectively grabs onto the basket full with mushrooms, the other holds a knife with its blade directed towards the viewer, suggesting that the potential victim of the stabbing is the reader of The Daily Express. The two images thus effectively convey the newspaper article's key message: it is not only British forests and edible mushrooms that are threatened by the invasion of gangs from Eastern Europe, but also the nation and its people. The United Kingdom - this at once material and fantasised entity - is taken hostage by the immigrants.

\section{ENGLISH NATIONALISM IN THE SHADOW OF THE NEW FOREST}

Employing similar techniques to those Ahmed identified in criminal prevention discourses and neighbourhood watch programmes (2000: 21-38), 'Eastern European mushroom mobs' incites the fantasy of the idealised community and the demarcation of outsiders. It represents a discourse of survival, where the communities of those posited as normal citizens and their spaces are represented as being in crisis. Such representation of the here and now enables the idealisation of what is assumed to be absent: a fantasy of the community and its spaces as valuable and innocent. As Ahmed (2000: 27) argues, this investment plays a significant role in the preservation of the unequal social order. It binds the protection of property and maintenance of social privilege and, simultaneously, conceals the social histories of conflict, exploitation and violence that have instituted them. This time, however, the site in crisis is not an urban space but a forest. I argue that encounters which do not take place only in humanspecific contexts but involve sites that are usually considered to be outside of culture and history - and forests and their wildlife in particular - significantly amplify certain aspects of othering. 
It can be argued that - through analogy - the context of what is considered to be 'nature' helps detach those who are subjected to othering from their social histories, and to fortify the metonymic associations that constitute their figuration. In other words, in the proximity of 'nature' it is easy to make othering look 'natural' - to represent otherness as an inherent quality, to normalise it and to justify othering as morally right. However, in addition to this general point, I put forward the following argument: locating a narrative of othering within the forest intensifies the fundamental aspect of othering, the sharing of a fantasy of an idealised 'we' which rests on the representation of community's presence as being in crisis.

The intensification of othering within the forest is due to the position forests have occupied in the cultural imagination of European colonial modernity and particularly in the formation of British nation state and its correlate, English nationalism. As Forest: The shadow of civilization (Harrison, 1993) testifies, forests have been understood as standing for an 'outside' (the Latin origin of the word 'forest' - foris - translates as 'outside') that constitutes the 'inside' of sociality and continues to haunt it. However, as anthropologists and historians of forests (Rackham, 2006; Schama, 1996; Tsing, 2005) have demonstrated, such an idea has its origin in a particular social and historical context - forests' outsideness is made possible by making them, both materially and discursively, wild and empty spaces of asocial nature. Only through oppressive practices - such as the evictions of peasants and the enclosures of woodland and other commons for the use of national élites - has the formation of European modernity and the regimes that define it, such as capitalism, imperial colonialism, nationalism, racism and heteropatriarchy, been made possible. In relation to the British context specifically, the UK's current woodland is far from being a residue of an original primeval wildwood. As Oliver Rackham (2006: 85) argues, English woods - in contrast to woodland in other parts of Europe such as Scotland, Poland or Germany - have been busy social and commercial sites especially since at least the Roman period (40-410 AD). In the UK, the name 'Forest' furthermore, has not signified a particular topography but administration - the legal demarcation of royal gaming reserves. Through decrees, this administration was 'imposed on large areas of the English countryside (...) that were not wooded at all, and which included tracts of pasture, meadow, cultivated farmland, and even towns (Schama, 1996: 144). Ironically enough, this new forest regime has not been initiated by the English royalty but Normans, commencing with the foundation of the New Forest by William the Conqueror around 1079. As Simon Schama (1996: 140) argues, the competition over privileges and power to exploit the woodland between the different propertied élites, namely the royalty, nobility, and the church - triggered by this new forest regime - gave rise to a myth about 'ravening Norman despotism annihilating whole villages and parishes to create private hunting reserves of the New Forest'. This myth was then foundational to yet another widely popular and still influential myth specific to English folklore - a myth of greenwood freedom and pre-feudal reciprocal social order that had allegedly taken place prior to Norman invasion, narrated since the Middle Ages through the figure of a heroic outlaw.

As follows from Schama's analysis, forests have not only been significant in English folklore and popular culture but have been entangled in the formation of the British nation-state and national belonging. Furthermore, this entanglement has not been only material or administrative but has, from the very start, involved the working of fantasy and imagination. Imagined as 'a shadow of civilization', English forests have been made to reflect a fantasy of the idealised 'we' of the nation through the demarcation of outsiders; a fantasy that has also been foundational to English nationalism - a fantasy of a defiance against ruling elites associated with foreignness.

My reading of The Daily Express newspaper article shows how this entanglement that links othering, nationbelonging, forests, mushrooms, and their foragers, continues to unfold in the context of the Brexit campaign. As argued earlier, it is not only the British forests and their wildlife that are presented as valuable and innocent and currently under attack by immigrants from Eastern Europe. The object of the nostalgia is also that which the forests and its wildlife are meant to 'shadow' - the nation and its people. The nationalist anti-immigration rhetoric mobilised in 'Eastern European mushroom mobs' thus can be interpreted as echoing the myth which has accompanied the foundation of the New Forest, and as contributing to the shared fantasy that has been circulating in England and later in the UK since the Middle Ages - the idealisation of the time before the invasion of (Norman) intruders. The Brexit campaign can be considered the most visible and effective recent mobilization of this fantasy. Addressed through the discourse on forests, mushrooms and their foragers constructed in The Daily Express, Brexit could - indeed - be seen to provide a solution to the problem raised in 'Eastern European mushroom mobs', although it is not the solution the newspaper article called for - instead of mushroom picking, what Brexit promises to 'ban' are the immigrants. Yet, according to environment review reports (Jennings, 2017), as a result of the termination of EU natural habitats conservation and wild species protection policies as well as investment and subsidies, Brexit is likely to bring new problems for British natural conservation sites and their wildlife. As the statement issued by Brian Tarnoff, the spokesperson of the New Forest Association, puts it (2016), '[h] owever we feel about the Brexit referendum, its aftermath has introduced a vast array of uncertainty, including many elements key to the future of the Forest'. 
Feminist Encounters: A Journal of Critical Studies in Culture and Politics, 5(1), 05

\section{BREXIT, THE EU, AND THE RACIALISED LEGACIES OF EUROPEAN IMPERIAL COLONIALISM}

The yearning for an idealised culturally and ethnically homogenous nation and its great past, however, does not define only the current political climate of the UK. As we witness the re-emergence of the right-wing populism across the world, anti-immigration narratives - such as the one constructed in 'Eastern European mushroom mobs' - together with racism, homophobia, transphobia, classism and sexism have, unfortunately, come to define the mainstream political vocabulary (Virdee and McGeever, 2018: 1802). In the UK it might, among many, be 'Eastern Europeans' who are at the receiving end of the anti-immigration outcry. 'At home', however, those who are figured as 'strangers' and feared as dangerous in the UK become the 'normal citizens' in need of protection from other others figured as dangerous strangers. ${ }^{4}$ The way othering operates - and benefits those who have been associated with white, masculine, heterosexual, cisgender and non-disabled bodies in the Global North and/or West at the expense of those who have not - is contextual, contradictory and fluid.

I therefore want to make clear that the intention of my contribution is not to reiterate the claim to victimhood and innocence of white Central and Eastern Europeans as has often been done in an attempt to negotiate the complex and complicit relationship with European colonial modernity (Tlostanova, 2014) also revealed within the context of Brexit (Emejulu, 2016). Especially after the end of socialism, in Central and Eastern European countries where the majority of the population has not been coded as racially, religiously or civilisationally absolutely differently from 'core Europeans', nationalism and the unspoken insistence on whiteness have become the most effective means of asserting Europeanness (Imre, 2005: 82). Furthermore, as Akwugo Emejulu (2016) rightly points out, the hostility, exploitation and violence which white immigrants from Central and Eastern Europe have experienced in the UK before and after Brexit unfortunately do not guarantee any imperative to dismantle racial hierarchy and racism.

Similarly, neither do I want to join the scolding of The Daily Express or its readers in a way it has predominantly been done in other - more liberal - mainstream British media, such as The Guardian or BBC news. Continuing the framing that has governed the mainstream antiracist and pro-immigration discourses in Europe since the end of the Second World War, they tend to produce individualising and psychologising accounts that frame migratism and racism as an interpersonal prejudice of flawed individuals or groups whose believes are incompatible with 'European' values (Lentin, 2004). In relation to Brexit specifically, as Bhambra (2017) has shown, such interpretation feeds into the argumentation of populist right-wing politicians who have claimed that the reasons for the opposition to immigration were merely economic, constructing the 'white working class' - whose grievances have for decades been allegedly ignored by liberal cosmopolitan elites - as the principal victim. However, as Bhambra further argues (2017), despite the appeal and seeming explanatory power of this discourse uncritically adopted across political elites, the mainstream media as well as scholarship, the centrality of race and racism to Brexit campaign is undeniable. Furthermore, although the present racism in the UK is intrinsically bound to English nationalism and its correlate, the longing for the British Imperial project, it is however not idiosyncratic. It feeds on and further reinforces the racial hierarchy that has defined the European colonial modernity and its political structures - the nation state, liberal democracy as well as supranational formations such as the EU, which especially after the joining of Central and Eastern European countries in 2004 became the 'Fortress Europe' that aggressively implements structural heteropatriarchal migratism, racism and classism on populations across its borders (Gržnić, 2014: 129).

Instances of othering such as the one produced by Brexit campaign's racist migratism therefore demand an intellectual and political response that would be different from simply taking a 'pro-immigration' and/or pro-EU stance. As follows from the work of Ahmed (2000: 9-10) and Bhambra (2017), a response which would enable to contest the material, discursive and fantasised structures that produce and naturalise othering needs to begin with the understanding that gendering racialisation - understood not as a continuous line but as a series of discontinuous encounters - have been a central principle of European colonial modernity that continues to configure our present.

To contribute to this endeavour from within scholarship with fungi, in the rest of the article, I will briefly discuss two instances of 'othering mushrooms' in European modern history. The first example is a Nazi antisemitic propaganda Der Giftpilz. (1938) which, as Mary Mills argues, represents 'the most extreme anti-Semitism imaginable' (1999). To critically examine its techniques of othering, the following section includes copies of two illustrations

\footnotetext{
${ }^{4}$ For instance, in 2018 communal elections in the Czech town Most, a party called Open Townhall based their campaign on a racist slogan 'disinfection is not enough to exterminate these vermin', which referenced Nazi antisemitic propaganda, and where vermin referred to Roma people (see romea.cz, 2018). Similarly, dehumanising language that compares immigrants to 'swarms' and 'cockroaches' has been used during the Brexit campaign (see Mcguire, 2019).
} 


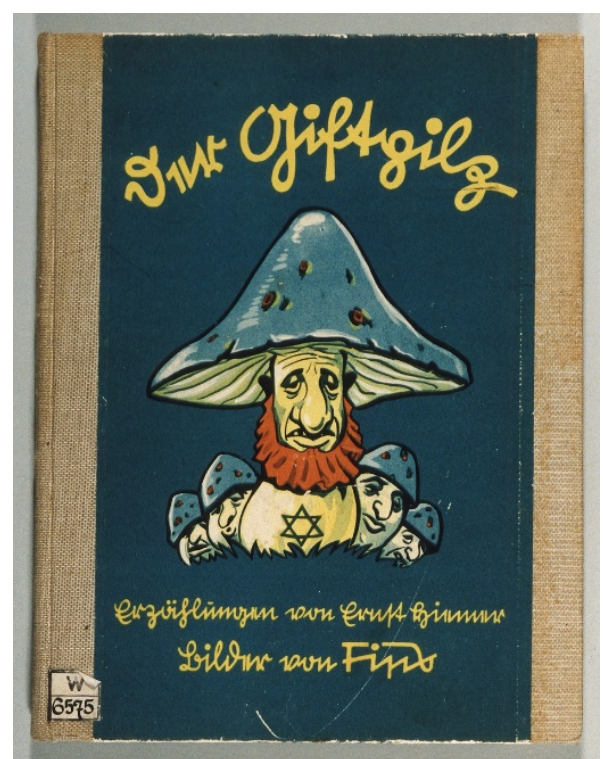

Figure 3. The cover of the antisemitic German children's book Der Gifttilz (1938). United States Holocaust Memorial Museum. https://collections.ushmm.org/search/catalog/pa1069698

and a few direct quotations. The second example involves examining the antisemitic underpinnings of the history and taxonomy of a mushroom species, Auricularia auricula which has been known in many European languages as the 'Ear of Judas' and in English under its even more problematic rendering 'Jew's Ear'.

\section{ANTISEMITIC ENTANGLEMENTS: OTHERING MUSHROOMS IN NAZI PROPAGANDA AND THE HISTORY AND TAXONOMY OF AURICULARIA AURICULA}

The antisemitic propaganda children's picture book Der Giftpilz ('the poisonous mushroom' or 'toadstool' in English translation) was first published by the publisher of the antisemitic tabloid Der Stürmer in Nazi Germany in 1938 (Goutam, 2014: 1019) and was recently republished by alt-right and neo-Nazi groups in countries such as the United States (Rose, 2008) and Czechia (Režňáková, 2020). ${ }^{5}$ As Mills (1999) argues, the purpose of the book was not only to incite fear and hate but also activate engagement in the persecution of Jews, paving the way and explicitly calling for the 'Final Solution' in the extermination of Jewish population.

The publication relies on the dehumanisation of Jews through a comparison with poisonous mushrooms. To create the image of an impossible and phobic object that threatens to poison and destroy individuals as well as nations, the publication employs techniques of othering through verbal as well as visual means. A caricature of a Jewish man as toadstool that features on the book's cover (Figure 3) includes the Star of David at the bottom of the mushroom's stem and exaggerates features that are crude stereotypes of Jewish appearance such as a crooked face, thick lips, a large bent nose, and a beard. The red of the beard could also be read as pointing to the alleged connection between Jews and another demonised group in Nazi Germany, the communists, as well as an indication of the mushroom's toxicity. The beard forms a ring on the mushroom's stem which is characteristic for amanitas, a genus that includes some of the most known toxic mushrooms. The caricature invokes two amanitas in particular - Amanita phalloides, in English called the death cap, and Amanita muscaria, known as the fly agaric. Finally, that the mushroom is poisonous is also suggested by the expression in man's face that demonstrates the effects of the malignant poisoning he is supposed to cause to the bodies of others.

Following the theme of poisonous mushrooms, the book thematises a key and distinct feature of modern antisemitism - the obsession with the ability to identify a Jewish person. As Alana Lentin (2004: 58-60) argues, '[m]odern antisemitism was born not from the great difference between groups but rather from the threat of absence of difference' which was a result of 'Jews' relative integration into bourgeois society' and 'the imposition of increasingly narrow definitions of belonging' in European nation states. The theme of correct identification is developed throughout the whole book. It opens with a story set up during mushroom picking in the forest (Figure 4), where a mother teaches her son, through a comparison between edible and poisonous mushrooms, the difference between good and bad people (the bad ones being Jews). The publication also lists the allegedly Jewish features, most of which define the stereotypes of Jews that endure to this day. For instance, in addition to

\footnotetext{
${ }^{5}$ All citations from the English translation of Der Giftpilz used in this article are accessible at the online German Propaganda
} Archive of Calvin University, (see German Propaganda Archive n.d.). 


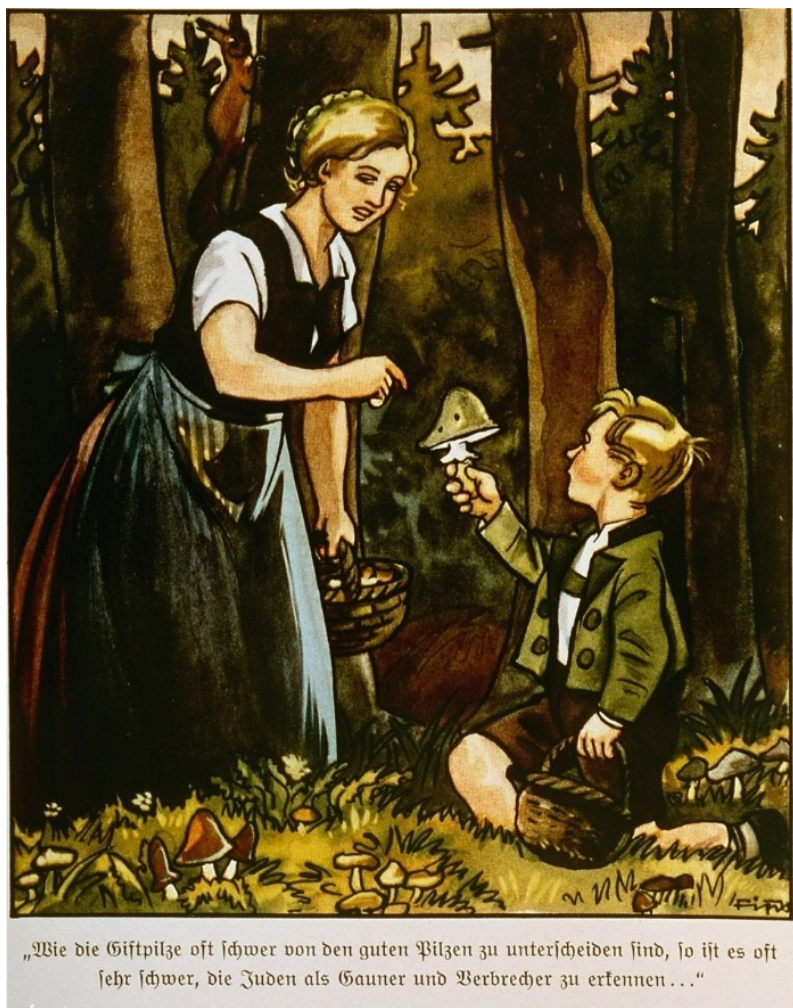

Figure 4. A page from the antisemitic German children's book Der Giftpilz (1938). The text reads: 'Just as it is often very difficult to tell the poisonous from the edible mushrooms, it is often very difficult to recognise Jews as thieves and criminals ...' United States Holocaust Memorial Museum. https://collections.ushmm.org/search/ catalog/pa1069700

the distinct shape of a nose, the list also includes 'filthy protruding large ears'. Additionally, Der Giftpilz, charges Jews with various crimes, creating a phantasmatic and contradictory image of key agents of capitalism (as bankers and usurers) as well as those who threaten the capitalist status quo (as socialists and communists). Jews are also portrayed as those who molest, kidnap, and sexually abuse children, women and torment animals, whilst simultaneously being infantilised and reduced to animality and thus denied their humanity. The book also employs religious antisemitism, charging Jews with the killing of the Jesus Christ, and reviving and manipulating the medieval image of a Jew as an incarnation of the Devil.

Finally, some of the rhetorical tropes of othering encountered in 'Eastern European mushroom mobs', although in a much more amplified and explicit manner, are employed in Der Giftpili. This includes the invocation of the overabundance of those identified as intruders which, in this case, is constructed through an analogy with poisonous mushrooms: 'Just as poisonous mushrooms spring up everywhere, so the Jew is found in every country in the world' claims the Nazi antisemitic propaganda. As Neil MacMaster argues (2001: 92), the association between Jews and mushrooms that connects both to the danger of decadence, degeneration and disease, became common in the nineteenth century through 'images or metaphors of the Jews as a monstrous fungus, a parasitic growth that fed upon the healthy body of the host society, finally reducing it to an emaciated and sickly shell'. Furthermore, Lentin argues that the fear of 'Jews being everywhere' is linked to a key feature of modern antisemitism mentioned above, the obsession with being able to identify a Jewish person. The invocation of overabundance in the sense of quantity ('being too many') as well as boundlessness ('being all over the world') implies a threat of intruders attacking and overwhelming the nation in large numbers from the outside, as well as the danger of the nation's destruction from the inside through anti-national sentiments such as cosmopolitanism (MacMaster, 2001: 92-93; Lentin, 2004: 60-62). The protection of children's innocence and purity, which The Daily Express newspaper article invokes only through a brief comment about families, is however central to Der Giftpilz and fulfils two distinct functions. Firstly, 'German children' function as a 'site' through which the border between the 'we' of the community and the feared and hated intruders is established. Secondly, it aims to build determination to actively participate in the persecution and extermination of Jews in its primary audience, the German children themselves.

That the medium which conveys such extreme antisemitism is a children's picture book should come as no surprise. As decolonial feminist philosopher Rozena Maart (2014: 8-11) argues, the global white hegemonic culture relies on the reproduction of racism in fairy tales told to children about the native and the indigenous as a villain, hiding in the depths of woods, ready to kill and destroy their family. In relation to fairy tales specific to Europe, Rozena Maart's analysis shows how othering operates in relation to the figure of a witch. She contends that the 


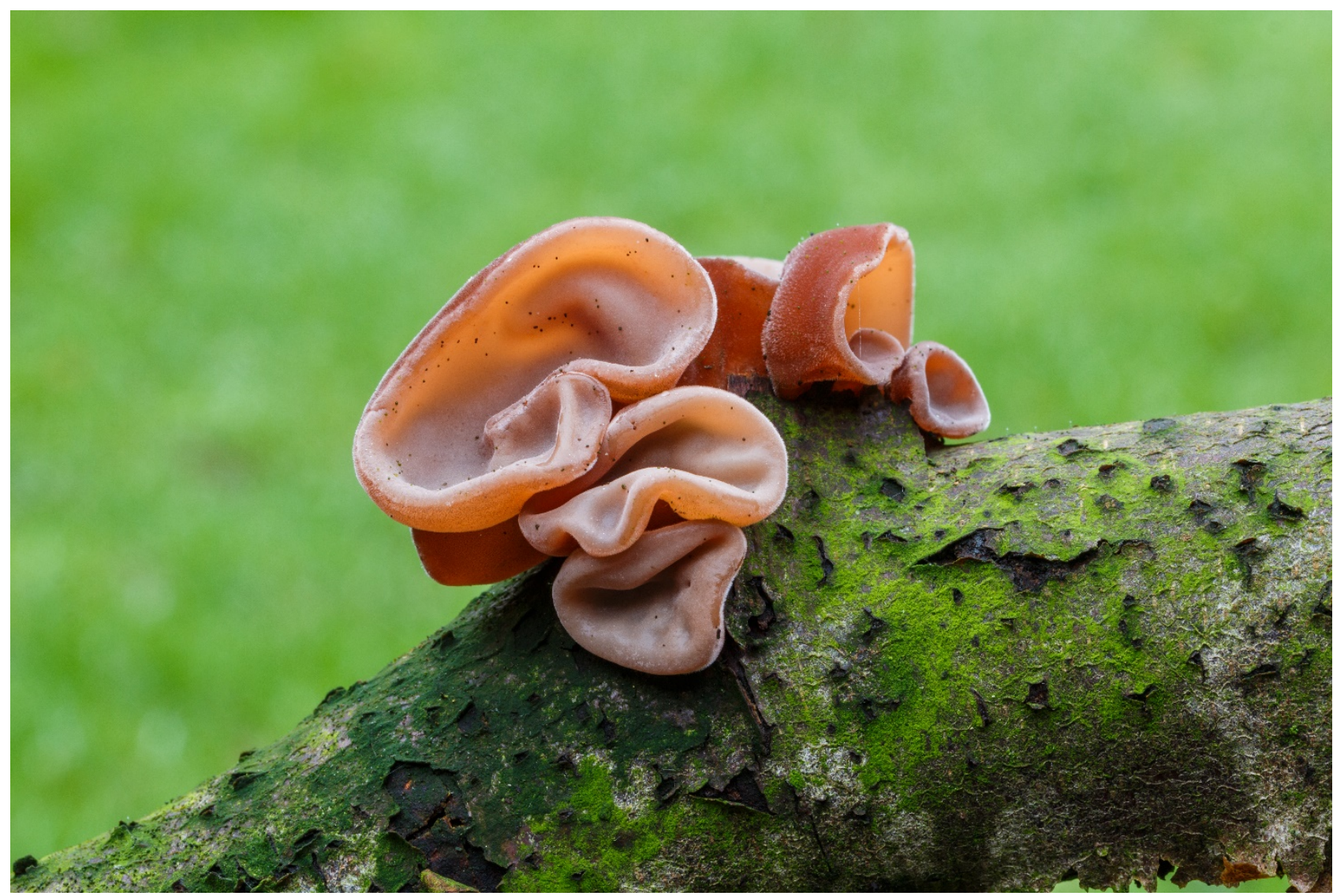

Figure 5. Auricularia auricula-judae (Family Auriculariaceae) on dead branch. (2016). Wikipedia Commons. https://commons.wikimedia.org/wiki/File:Echt_judasoor_(Auricularia_auricula-judae)_Familie _Auriculariaceae_op_een_dode_tak_03.jpg

representation of witches is not only a result of heteropatriarchal gendering that demonises and brutalises proletariat and peasant adult and older women but is also racialised - the witch is a representation of a Jewish woman, characterised as dark and physically deformed, with crooked features. As Rozena Maart (2014: 19) further postulates, the treatment of Jewish people has been reminiscent of the way other 'othered' groups such as Travellers, Roma, Black, Asian, Indigenous (such as Sámi in the Nordic region) and other ethnic minorities have been treated in European colonial modernity. To invoke Ahmed's framework again, this has also proceeded through forging bodily metonymic associations between these groups, which, in Der Giftpilz, is enacted through the comparison between the hair of Jewish and African people (see also Lentin, 2004: 50). However, as Rozena Maart in accordance with other scholars postulates (2014: 19), racism - as well as its particular form as antisemitism - are global phenomena that predicate the rise of Nazism in central Europe in the 1930s and conceptualise gendering racialisation as an organisational principal of European colonial modernity that is written not only into state structures and practices but also into common sense, folk knowledge and modern science.

My second example, which involves the history and taxonomy of a species of mushroom of a Latin name Auricularia auricula - a joint creation of European folk and scientific nomenclature - illustrates this point. This mushroom, in English known under various names such as 'Jelly Ear' or 'Wood Ear' is a widely distributed pinkishbrown to dark brown mushroom distinctive for its ear-like shape (Figure 5). Depending on age and water content, its texture varies from that of a slimy gelatine, an elastic with soft velvety surface, to a tough wrinkled rubber that becomes hard and brittle when old or dried. Auricularia auricula grows in stem-less clusters on dead and living wood, especially elder. It can be found throughout out all seasons in temperate and sub-tropical regions worldwide especially in damp and shaded areas. The reason why Jelly Ears are so prolific is also because of their host, the elder tree, which can be found almost everywhere, and is sometimes itself considered an invasive alien species (Antonsich, 2020). Elder grows on the edges of fields and woods, even in cities and towns where it is traditionally cut back. Auricularia auricula is edible and has also been used in medicine. It is popular in Asia, especially in China, where it is called 黑木耳 [Hei mu er], 'black wood ears' in translation. ${ }^{6}$ In Europe, however, this mushroom is neither sought-after by mushroom foragers nor is it widely consumed.

${ }^{6} \mathrm{I}$ am grateful to Bing Wang and Yelin Zhao for clarifying the nomenclature of Auricularia Auricula in Mandarin. 
As ethnomycologist David W. Rose (2008: 13) argues, in Europe, Auricularia auricula has been widely recognised as a distinctive mushroom species at least since the sixteenth century. It has appeared under its Latin medieval name auricula Judae which in translation means 'Ear of Judas', a name which the scientific nomenclature also adopted in the nineteenth century. This name still features in some of the current mycology books (as Auricularia auricula-judae) and matches the vernacular name in most European languages (Ucho Jidásovo in Czech, Oreille de Judas in French, Das Judasohr in German, or Jundaksenkorva in Finnish), including English, where the mushroom is not called 'Judas' ear' but 'Jew's ear'. Most commonly, mycology literature maintains that the name 'Judas' ear' is derived from the belief that Judas Iscariot, after betraying Jesus Christ, hanged himself from an elder tree, and treats the shift from 'Judas' Ear' to 'Jew's Ear' as a mistranslation. However, Rose's (2008: 13-14) detailed philological analysis shows how the names 'Judas' ear' and 'Jew's ear', which both have been in circulation already in the sixteenth century, are a result of widespread antisemitism characteristic of European medieval folk knowledge as well as of another system of knowledge which appeared with modernity - scientific taxonomy and systemics predicated upon the Linnaean binominal system of classification and hierarchisation of life forms (Money, 2013).

Drawing from the previous analyses and following on from Ahmed's conceptualisation of othering as an embodied process, I want to add a further point to Rose's philological analysis. After a brief encounter with $D e r$ Giftpils, which includes among the alleged characteristic features of Jewish people 'filthy protruding large ears' and complains about the overabundance of Jews through the analogy with poisonous mushrooms, as well as Rozena Maart's analysis of witches as a representation of Jewish women characterised as dark and with physically deformed crooked features who hide in the depth of the woods, it is evident that the roots, or perhaps more accurately byphae - of the antisemitism of the history and taxonomy of Auricularia Auricula is not only linguistic or discursive but also bodily. This is however not to argue that the otherness is found on or in Jewish bodies - or the bodies of certain mushrooms - as if these bodies and the way they inhabit spaces were the origin of this otherness. For instance, consider the antisemitic association between mushrooms, overabundance, and Jewish people, which is central to Der Giftpilz and the naming of Auricularia auricula as Judas' Ear/Jew's Ear, and how it is echoed in the othering of the Brexit campaign. Here the overabundance - as a sign of the danger and potential harm - is distributed differently. Whereas the sense of 'being too many' is assigned to those positioned as intruders, that is to say to immigrants and especially those who are not white, the sense of 'being all over the world' - the charge of anti-nationalist sentiments such as cosmopolitism - is raised also against the liberal elites that are cast as the enemy of 'ordinary people' (here meaning 'the white working class'). Within the context of the Brexit campaign, this racially coded, nationalist anti-élite sentiment was perhaps most visibly expressed by the Tory Party Prime Minister Theresa May in a speech delivered after the EU Referendum vote (Pitcher, 2019: 2494) where May insisted that 'if you believe you're a citizen of the world, you're a citizen of nowhere'.

\section{CONCLUSION}

In Strange Encounters (2000), Ahmed provides a theorisation of a mode of embodying subjectivities that has dominated the world since the beginning of European colonial modernity, and that has benefited those who have been associated with white, masculine, heterosexual, cisgender and non-disabled bodies in the Global North and/or West at the expense of those who have not. Mobilising this theorisation, the analyses presented in this article show how this mode of othering embodied subjectivities is thoroughly dependent not only on humancentred cultural and historical contexts, but also on what is traditionally considered to be situated outside of them, such as geology, climate, and biodiversity. As the above analyses further demonstrates, research with fungi that specifically takes the polarised sentiments towards these organisms not as exclusive binaries but as critically entangled and mutually constitutive cultural positions, becomes a particularly potent means to study how otherness is constructed and embodied in human and non-human bodies and the places they inhabit. This also holds particularly for the interrogation of phenomena such as right-wing populism, which has re-emerged across the world and that in Europe is exemplified by events such as Brexit, and where the extreme polarisation of a binary native/alien dichotomy has become the underlying logic.

Although othering proceeds along the established binaries such as native/alien and its correlates human/nonhuman, citizen/foreigner, male/female, civilised/primitive, Global North/South and West/East, the way it proceeds is neither uniform nor clear-cut. As showed with my analysis of how overabundance - as a sign of danger and potential harm - has figured in The Daily Express newspaper article 'Eastern European mushroom mobs,' the antisemitic Nazi propaganda children's picture book Der Giftpils, and the history and taxonomy of a mushroom species Auricularia auricula, overabundance is distributed differently across the various bodies of humans and nonhumans in these three instances of 'othering mushrooms'. The way in which a knife figures in the photographs that accompany The Daily Express newspaper article discussed in the first section of my contribution can serve as another example. Here a knife does not invoke techniques of careful harvesting which foragers use to pick 
mushrooms without disturbing or damaging the fungus' hyphae but as a harmful attack. As I argued previously, the way othering operates is contextual, complex, and fluid; sometimes it is even contradictory.

The specific contribution which my examination of how mushrooms have been deployed as a means of othering within the context of the Brexit campaign can be summarised as follows. Firstly, the close analysis of The Daily Express's article 'Eastern European mushroom mobs' demonstrates how it draws from and further reinforces white heteropatriarchy. Situating a narrative of othering within what is considered to be 'nature' amplifies certain aspects of this process. On the one hand, the proximity of nature makes othering look natural, it helps to represent otherness as an inherent quality, to normalise othering and justify it as morally right. On the other hand, locating a narrative within a forest and its wildlife intensifies a fantasy of an idealised community that rests on the representation of community's presence as being in crisis. This is, as I demonstrate, due to the position forests have occupied in the cultural imagination of European colonial modernity, and particularly in the UK.

This article also demonstrates how research into social and environmental histories - and the histories of forests and their wildlife in particular - is vital for the critical interrogation of the recent re-emergence of the right-wing populism, exemplified by Brexit. In relation to forests and the role they have played in the formation of English nationalism that is bound to the past and present legacies of British Empire, I show how the Brexit campaign can be considered to be the most visible and effective recent mobilisation of a myth of greenwood freedom that has been circulating in England and later in the UK since the Middle Ages. In relation to European colonial modernity and the gendering racialisation which is its central organising principal, I show how the Brexit campaign emerges from and reinforces European antisemitic discourse. More specifically, I show that it mobilises tropes of othering that are reminiscent of antisemitism that has underpinned European folk knowledge as well as modern science. However, more disturbingly, my analysis of the tropes of othering mobilised in 'The Eastern European mushroom mobs' also shows that it is reminiscent of othering techniques deployed in Der Gifttilz - a publication which aimed not only to incite fear and hate but also activate engagement in the persecution and extermination of Jewish populations. This supports and develops work by scholars (such as Mcguire, 2019) who have called attention to the similarities between the rhetoric used in the Brexit campaign and that of Nazi propaganda. As argued above, a response which would enable to contest the material, discursive and fantasised structures that produce and naturalise othering would need to include the understanding that gendering racialisation has been a central principle of European colonial modernity that continues to configure our present. In this article, I try to contribute to this project by following mushrooms.

\section{ACKNOWLEDGMENTS}

I am grateful to the guest editors of this special issue, Amanda Gouws, Azille Coetzee and Deirdre Byrne, and the anonymous reviewers for their support and valuable comments. My thanks also go to Sveta Yamin-Pasternak for sharing her insights into ethnomycological research on antisemitism and to fellow members of the 'Sisters of the Spore' feminist writing collective for their feedback on the first draft of the article. I am also grateful to Marsha Meskimmon and Elspeth Mitchell whose insights into the feminist study of fungi in visual culture have been indispensable for the analyses presented in the article.

\section{REFERENCES}

Ahmed, S. (2000). Strange Encounters: Embodied others in post-coloniality. London and New York: Routledge.

Ahmed, S. (2013). The Cultural Politics of Emotion. London and New York: Routledge. https://doi.org/10.4324/ 9780203700372

Antonsich, M. (2020). Natives and Aliens: Who and What Belongs in Nature and in the Nation?. Area, 00, 1-8. https://doi.org/10.1111/area.12679

Bahng, A. (2017). Plasmodial Improprieties: Octavia E. Butler, Slime Molds, and Imagining a Femi-Queer Commons, in C. Cipolla, K. Gupta, D. A. Rubin and A. Willey (eds), The Queer Feminist Science Studies Reader (pp. 310-326). Seattle: University of Washington Press.

Bhabha, H. K. (1983). The Other Question.... Screen, 24(6), 18-36. https://doi.org/10.1093/screen/24.6.18

Bhambra, G. K. (2017). Locating Brexit in the Pragmatics of Race, Citizenship and Empire, in William Outhwaite (ed), Brexit: Sociological Responses (pp. 91-99). London and New York: Anthem Press.

Buckledee, S. (2011). Tabloid Newspapers and National Identity: Reporting Reality or Fabricating a Myth?, in Biljana Đorić-Francuski (ed), Image-Identity-Reality (pp. 59-74). Cambridge: Cambridge Scholars Publishing.

Conboy, M. (2006). Tabloid Britain: Constructing a community through language. Oxon and New York: Routledge. 
Emejulu, A. (2016). On the Hideous Whiteness Of Brexit: 'Let Us Be Honest about Our Past and Our Present If We Truly Seek to Dismantle White Supremacy'. Versobooks.Com (blog). Available at: https://www.versobooks .com/blogs/2733-on-the-hideous-whiteness-of-brexit-let-us-be-honest-about-our-past-and-our-present-ifwe-truly-seek-to-dismantle-white-supremacy. (Accessed 28 November 2020).

German Propaganda Archive (n.d.). Der Giftpilz, (Ernest Hiemer, 1938). Available at: https://research.calvin.edu/ german-propaganda-archive/thumb.htm. (Accessed 5 June 2020).

Goutam, U. (2014). Pedagogical Nazi Propaganda (1939-1945). Proceedings of the Indian History Congress, 75, 10181026.

Gržnić, M. (2014). Europe's Colonialism, Decoloniality, and Racism, in S. Broeck and C. Junker (eds.), Postcoloniality - Decoloniality - Black Critique: Joints and fissures (pp. 129-144). Frankfurt and New York: Campus Verlag.

Harrison, R. P. (1993). Forests: The shadow of civilization. 1st edition. Chicago and London: University of Chicago Press.

hooks, b. (1992). Eating the Other: Desire and Resistance, in Black Looks: Race and representation, 33-52. Boston, MA: South End Press.

Imre, A. (2005). Whiteness in Post-Socialist Eastern Europe: The Time of the Gypsies, the End of Race, in A. J. López (ed), Postcolonial Whiteness: A critical reader on race and empire (79-102). Albany, NY: SUNY Press.

Jennings, K. (2017). Brexit and Nature Conservation: An Opportunity or a Threat?. UK in a Changing Europe (blog). 18 August. Available at: https://ukandeu.ac.uk/brexit-and-nature-conservation-an-opportunity-or-a-threat/ . (Accessed 28 November 2020).

Lentin, A. (2004). Racism And Anti-Racism In Europe. London: Pluto Press.

Maart, R. (2014). Philosopby Born of Massacres. Marikana, the theatre of cruelty: The killing of the 'kaffir'. Available at: http://scholar.ufs.ac.za/xmlui/handle/11660/3037. (Accessed 7 October 2020).

MacMaster, N. (2001). Racism in Europe: 1870-2000. New York: Macmillan International Higher Education. https://doi.org/10.1007/978-1-4039-4033-9

Mcguire, K. (2019). Engaging with the Media in a Pre and Post Brexit World: Racism, Xenophobia and Regulation: A United Kingdom Perspective. Journal of Hate Studies, 15(1), 255-273. https://doi.org/10.33972/jhs.170

McKie, R. (2016). Free-for-All by Wild Mushroom Pickers Puts Woodland Habitats at Risk. The Observer, 3 September. Available at: https://www.theguardian.com/science/2016/sep/04/new-forest-bans-fungi-pickers. (Accessed 12 November 2020).

Mills, M. (1999). Propaganda and Children During the Hitter Years. Available at: https:/ /www.jewishvirtuallibrary.org/ propaganda-and-children-during-the-hitler-years. (Accessed 28 November 2020).

Money, N. P. (2013). Against the Naming of Fungi. Fungal Biology, 117(7), 463-465. https://doi.org/10.1016/j.funbio.2013.05.007

Perring, R. (2015). Eastern European Mushroom Mobs: New Forest Is Stripped Bare by Fungi Rustlers, Express.co.uk, 16 July. Available at: https://www.express.co.uk/news/uk/591570/Gangs-mushrooms-blackmarket-New-Forest-Eastern-European-fungi. (Accessed 15 November 2020).

Pitcher, B. (2019). Racism and Brexit: Notes towards an Antiracist Populism. Ethnic and Racial Studies, 42(14), 2490_ 2509. https://doi.org/10.1080/01419870.2019.1623410

Rackham, O. (2006). Woodlands. London: Collins.

Režňáková, L. (2020). Obchody Nabízejí Protižidovskou Knihu pro Děti, Dílo Nacistické Propagandy IDNES.Cz, Idens.Cz, 2020. Available at: https://www.idnes.cz/zpravy/domaci/vydavatel-guidemedia-knihaantisemitismus-nabidka-odbornici-kniha-pro-deti-jedovata-houba.A200212_101418_domaci_lre. (Accessed 18 November 2020).

romea.cz (2018). Označoval Romy Za Medúzy. V Kampani Je Ted’ Jeho Hnutí Označuje Za Havèt', Na Kterou Nestač Deratizačni Prostrédky. Available at: http://www.romea.cz/cz/zpravodajstvi/domaci/oznacoval-romy-zameduzy-v-kampani-je-ted-jeho-hnuti-oznacuje-za-havet-na-kterou-nestaci-deratizacni-prostredky. (Accessed 18 November 2020).

Rose, D. W. (2008). Notes from Underground Auricularia Auricula, Anti-Semitism and Political Mushrooms. Fungi, 1, 12-17.

Schama, S. (1996). Landscape and Memory. New York: Vintage, A Division of Random House.

Sheldrake, M. (2020). Entangled Life: How fungi make our worlds, change our minds \& shape our futures. New York: Random House Publishing Group.

Tarnoff, B. (2016). Brexit and The Forest. Friends of the New Forest (blog). 20 July. Available at: http:// newforestassociation.org/brexit-and-the-forest/. (Accessed 22 November 2020).

Tlostanova, M. (2014). Why the Postsocialist Cannot Speak: On Caucasian Blacks, Imperial Difference, and Decolonial Horizons, in S. Broeck and C. Junker (eds), Postcoloniality - Decoloniality - Black Critique: Joints and fissures (pp. 159-73). Frankfurt and New York: Campus Verlag. 
Tsing, A. (2005). Friction: An ethnography of global connection. Princeton, NJ and Oxfordshire: Princeton University Press. https://doi.org/10.1515/9781400830596

Tsing, A. (2015). The Mushroom at the End of the World. Princeton, NJ and Oxfordshire: Princeton University Press.

Tudor, A. (2017). Queering Migration Discourse: Differentiating Racism and Migratism in Postcolonial Europe. Lambda Nordica, 22(2-3), 21-40.

Tudor, A. (2018). Cross-Fadings of Racialisation and Migratisation: The Postcolonial Turn in Western European Gender and Migration Studies. Gender, Place \& Culture, 25(7), 1057-1072. https://doi.org/10.1080/0966369X.2018.1441141

Virdee, S. and McGeever, B. (2018). Racism, Crisis, Brexit. Ethnic and Racial Studies, 41(10), $1802-1819$. https://doi.org/10.1080/01419870.2017.1361544

Wasson, V. P. and Wasson, R. G. (1957). Mushrooms, Russia, and History. New York: Pantheon Books.

Yamin-Pasternak, S. (2011). Ethnomycology: Fungi and Mushrooms in Cultural Entanglements, in E. N. Anderson, D. Pearsall, E. Hunn and N. Turner (eds), Ethnobiology (pp. 213-230). John Wiley \& Sons, Ltd. https://doi.org/10.1002/9781118015872.ch13

Citation: Vráblíková, L. (2021). Othering Mushrooms: Migratism and its racist entanglements in the Brexit campaign. Feminist Encounters: A Journal of Critical Studies in Culture and Politics, 5(1), 05. https://doi.org/10.20897/femenc/9742 